\title{
Detection of genes encoding for enterotoxins, TSST-1, and biofilm production in coagulase-negative staphylococci from bovine bulk tank milk
}

\author{
Fabrizio Bertelloni • Filippo Fratini • \\ Virginia Valentina Ebani • Alessia Galiero • \\ Barbara Turchi • Domenico Cerri
}

Received: 2 October 2014 / Revised: 14 January 2015 / Accepted: 15 January 2015 /

Published online: 4 February 2015

(C) INRA and Springer-Verlag France 2015

\begin{abstract}
Coagulase-negative staphylococci (CNS) represent common skin commensals in humans and other mammals. They are opportunistic microorganisms and, in dairy production, are considered as minor pathogens, often associated to subclinical mastitis. It has been recently demonstrated that CNS can produce Staphylococcus aureus superantigens, as well as biofilm. In our study, 74 CNS were isolated from Tuscan (Central Italy) bovine bulk tank milk and phenotypically identified as Staphylococcus xylosus (28.4 \%), Staphylococcus chromogenes (20.3\%), Staphylococcus sciuri (12.2\%), Staphylococcus hominis (9.4\%), Staphylococcus haemolyticus (6.8 \%), Staphylococcus capitis (5.4\%), Staphylococcus cohnii ssp. cohnii (4.1\%), Staphylococcus saprophyticus (4.1\%), and Staphylococcus simulans $(4.1 \%)$. Moreover, one isolate $(1.3 \%)$ was detected for each of the following species: Staphylococcus caprae, Staphylococcus epidermidis, Staphylococcus lentus, and Staphylococcus warneri. All isolates were screened by PCR for the presence of genes encoding classical enterotoxins (sea-see), toxic shock syndrome toxin-1 (tst), and biofilm $($ icaA $/ D)$. Forty isolates $(54.1 \%)$ presented at least one gene encoding for enterotoxin production, $15(20.3 \%)$ harbored two or more genes in association. The most frequently detected gene was sea $(41.9 \%)$, followed by sec-1 $(25.7 \%)$. None of the tested isolates presented genes encoding for enterotoxin B or D. Fifteen isolates $(20.3 \%)$ presented genes encoding for biofilm production. Among these, 11 isolates also harbored genes encoding for enterotoxin production. Our results suggest that enterotoxigenic CNS could represent a potential reservoir of pathogenicity factors, which could substantially contribute to enhance $S$. aureus virulence when present in milk and milk products. Further investigations are required for the evaluation of enterotoxins and biofilm production.
\end{abstract}

F. Bertelloni $\cdot$ F. Fratini $\cdot$ V. V. Ebani $\cdot$ A. Galiero $\cdot$ B. Turchi $(\bowtie) \cdot$ D. Cerri Department of Veterinary Sciences, University of Pisa, Viale delle Piagge 2, Pisa, Italy e-mail: barbara.turchi@for.unipi.it 
Keywords Coagulase-negative staphylococci $\cdot$ Milk $\cdot$ Enterotoxins $\cdot$ TSST- $1 \cdot$ Biofilm

\section{Introduction}

Staphylococcal food poisoning (SFP) is one of the most prevalent causes of human gastroenteritis worldwide (Jablonski and Bohach 1999). It is mainly associated with Staphylococcus aureus strains able to produce thermostable enterotoxins (Dinges et al. 2000; Jorgensen et al. 2005; Le Loir et al. 2003; Payne and Wood 1974; Stewart et al. 2003). Foods of animal origin, particularly milk and dairy products, represent the main source of toxigenic strains and the direct vehicle from farm to consumers (Bendahou et al. 2008; Rall et al. 2008; Schmid et al. 2009). Staphylococcal enterotoxins (SEs) belong to the pyrogenic toxin superantigen family of exotoxins (PTSAgs), as well as toxic shock syndrome toxin-1 (TSST-1) (Dinges et al. 2000). Several SEs are designated as SE-like (SEl) toxins, because either they lack in emetic activity or emetic activity has not been tested yet (Lina et al. 2004; Omoe et al. 2005). So far, 21 SE and SEl toxins have been identified. SEA, SEB, SEC, SED, and SEE represent the wellcharacterized classical staphylococcal enterotoxins. Beyond these, 16 new types of SEs (SEG, SEH, SEI, SER, SES, SET) and SEls (SElJ, SElK, SElL, SEIM, SEIN, SElO, SElP, SElQ, SEIU, and SEIV) have been reported (Argudin et al. 2010).

While SE production by $S$. aureus has been well documented in the last decades (Dinges et al. 2000; Payne and Wood 1974; Rall et al. 2008; Schmid et al. 2009), researches concerning the ability of coagulase-negative staphylococci (CNS) to produce enterotoxins are increasing over the last few years (Aye et al. 2014; Oliveira et al. 2011; Ruaro et al. 2013; Zell et al. 2008).

Another relevant characteristic of CNS is the ability to produce biofilm, which allows microorganisms to survive in the environment, even in presence of disinfectants, and to evade host's defense (Otto 2013; Vanderhaeghen et al. 2014). In staphylococcal species, the intercellular adhesion (ica) locus, harboring the operon icaADBC, encodes proteins involved in the synthesis of polysaccharide intercellular adhesin (PIA) and capsular polysaccharide/adhesin (PS/A). The ica gene cluster seems to have a wide distribution among CNS species from different samples (Tremblay et al. 2013; Vanderhaeghen et al. 2014).

CNS are, usually, present on human and animal skin and mucous membranes, and they are easily isolated from environmental samples (Michael 2004; Piette and Verschraegen 2009; Seo et al. 2008). In dairy cattle, CNS were expected to be saprophytic or rarely pathogenic; however, they are often associated with subclinical udder infections, characterized by an increase of somatic cell in milk and in a decreased production (Bendahou et al. 2008; Lüthje and Schwarz 2006; Resch et al. 2008; Tenhagen et al. 2006; Zell et al. 2008). CNS could also be found in fermented dairy products, as they can easily tolerate acidity and salt (Irlinger 2008).

The aim of the present research was to evaluate the presence of genes encoding for the production of the major enterotoxins (A, B, C, D, E), toxic shock syndrome toxin-1 (TSST-1), and biofilm in CNS isolated from Tuscan (Central Italy) bovine bulk tank milk in order to estimate the possible risk for human 
health. Considering that the ability to form biofilm may result in an enhanced resistance in the environment, the simultaneous presence of genes encoding for both toxins and biofilm could represent a higher risk for public health.

At the present, studies on indigenous CNS from Italian milk and cheeses are limited (Ruaro et al. 2013). As far as we know, this is the first report concerning the detection of pathogenic factors in CNS isolated from Tuscan bovine bulk tank milk.

\section{Materials and methods}

\subsection{Samples collection}

In a period of time of 11 months, 120 bulk tank milk samples were examined to detect CNS strains. Three farms located in Livorno (A), Grosseto (B), and Pisa (C), three different Tuscan provinces, were included in our sampling design in order to get the more microbial diversity as possible. Three to four samples were monthly collected from each farm. Approximately $50 \mathrm{~mL}$ of bulk milk were collected aseptically in sterile plastic containers and quickly transported to the laboratory in refrigerated conditions.

\subsection{Obtention of isolates and phenotypic identification}

Each sample was plated on blood agar (Oxoid, Milan, Italy) supplemented with $5 \%$ of sheep blood and incubated aerobically for $24 \mathrm{~h}$ at $37^{\circ} \mathrm{C}$. After incubation, five single colonies were selected from each plate and subjected to Gram staining (Gram Staining kit, Sigma-Aldrich, Milan, Italy) and catalase test (Bartelt 2000). All presumptive staphylococcal strains were then tested for DNAse activity with DNase Agar (Oxoid) and for their ability to coagulate citrated rabbit plasma. DNAse and coagulase-negative isolates were selected for species identification by API 20 Staph system (BioMerieux, Marcy l'Etoile, France). After phenotypic identification, each isolate was cultured in $6 \mathrm{~mL}$ of Brain Heart Infusion broth (Oxoid) and incubated at $37{ }^{\circ} \mathrm{C}$ for $24 \mathrm{~h}$. After incubation, $1 \mathrm{~mL}$ of sterile glycerol was added to each broth culture, which was then stored at $-80{ }^{\circ} \mathrm{C}$ for further analysis.

\subsection{DNA extraction and enterotoxins and TSST-1 gene detection}

Each isolate was revitalized on Tryptone Soya Agar (Oxoid) at $37{ }^{\circ} \mathrm{C}$ for $24 \mathrm{~h}$. After incubation, a single colony was cultured in $6 \mathrm{~mL}$ of Brain Heart Infusion broth and incubated at $37{ }^{\circ} \mathrm{C}$ for $72 \mathrm{~h}$. DNA extraction was performed with DNeasy Blood \& Tissue Kit (Qiagen, Milan, Italy); broth cultures were centrifuged at 15,000 rpm for $10 \mathrm{~min}$, supernatants were discarded, and pellets were used for DNA extraction following the manufacturer's instruction.

PCR assays were carried out to detect genes encoding for enterotoxins A, B, C, $\mathrm{D}$, and E and TSST-1 production. Table 1 shows the list of primers employed in our study.

Each PCR amplification was performed in $50 \mu \mathrm{L}$ of reaction mixtures containing $200 \mu \mathrm{M}$ of deoxynucleoside triphosphates, $0.5 \mu \mathrm{M}$ of each primer, $1.25 \mathrm{U}$ of Taq polymerase (Qiagen), $5 \mu \mathrm{L}$ of $10 \times$ Qiagen PCR buffer, and $2 \mu \mathrm{L}$ of template. 
Table 1 Primers employed for the detection of genes encoding enterotoxins and biofilm production

\begin{tabular}{|c|c|c|c|c|}
\hline Gene & Primer & Sequence $\left(5^{\prime}-3^{\prime}\right)$ & Size (bp) & Reference \\
\hline \multirow[t]{2}{*}{ sea } & SEA F & TTG GAA ACG GTT AAA ACG AA & 120 & Johnson et al. (1991) \\
\hline & SEA R & GAA CCT TCC CAT CAA AAA CA & & \\
\hline \multirow[t]{2}{*}{$s e b$} & SEB F & TCG CATC AAA CTG ACA AAC G & 478 & Johnson et al. (1991) \\
\hline & SEB R & GCA GGT ACT CTA TAA GTG CC & & \\
\hline \multirow[t]{2}{*}{$\sec -1$} & SEC F & GAC ATA AAA GCT AGG AAT TT & 257 & Johnson et al. (1991) \\
\hline & SEC R & AAA TCG GAT TAA CAT TAT CC & & \\
\hline \multirow[t]{2}{*}{ sed } & SED F & CTA GTT TGG TAA TAT CTC CT & 317 & Johnson et al. (1991) \\
\hline & SED R & TAA TGC TAT ATC TTA TAG GG & & \\
\hline \multirow[t]{2}{*}{ see } & SEE F & TAG ATA AAG TTA AAA CAA GC & 170 & Johnson et al. (1991) \\
\hline & SEE R & TAA CTT ACC GTG GAC CCT TC & & \\
\hline \multirow[t]{2}{*}{ tst } & TSST F & ATG GCA GCA TCA GCT TGA TA & 350 & Johnson et al. (1991) \\
\hline & TSST R & TTT CCA ATA ACC ACC CGT TT & & \\
\hline \multirow[t]{2}{*}{$i c a A$} & icaA F & TCT CTT GCA GGA GCA ATC AA & 188 & Gad et al. (2009) \\
\hline & icaA R & TCA GGC ACT AAC ATC CAG CA & & \\
\hline \multirow[t]{2}{*}{$i c a D$} & icaD F & ATG GTC AAG CCC AGA CAG AG & 198 & Gad et al. (2009) \\
\hline & icaD R & CGT GTT TTC AAC ATT TAA TGC AA & & \\
\hline
\end{tabular}

PCR amplifications were performed in an automated thermal cycler (Gene-Amp PCR System 2700, Perkin-Elmer, Norwalk, CT, USA) for 30 cycles. Each PCR cycle consisted of an initial denaturation of $5 \mathrm{~min}$ at $94{ }^{\circ} \mathrm{C}$, denaturation at $94{ }^{\circ} \mathrm{C}$ for $2 \mathrm{~min}$, annealing at $55^{\circ} \mathrm{C}$ for $2 \mathrm{~min}$, extension at $72{ }^{\circ} \mathrm{C}$ for $1 \mathrm{~min}$, and a final extension of 5 min at $72{ }^{\circ} \mathrm{C}$. A control strain was included for each assay: $S$. aureus: ATCC 13565 for detection of sea, ATCC 14458 for seb, ATCC 19059 for sec-1, ATCC 23235 for sed, and ATCC 27664 for see. Staphylococcus epidermidis ATCC 12228 was used as a negative control.

PCR products were analyzed by electrophoresis on $1.5 \%$ agarose gel at $100 \mathrm{mV}$ for $45 \mathrm{~min}$; the gel was stained with ethidium bromide and observed at UV light. GelPilot 100-bp Plus Ladder (Qiagen) was employed as molecular weight marker.

\subsection{Biofilm gene detection}

The icaA and icaD genes were detected by PCR assays employing primers listed in Table 1. Each PCR amplification was performed in $50 \mu \mathrm{L}$ of reaction mixtures containing $200 \mu \mathrm{M}$ of deoxynucleoside triphosphates, $0.5 \mu \mathrm{M}$ of each primer, $1.25 \mathrm{U}$ of Taq polymerase (Qiagen), $5 \mu \mathrm{L}$ of $10 \times$ Qiagen PCR buffer, and $2 \mu \mathrm{L}$ of extracted DNA. The amplification consisted of an initial denaturation at $94{ }^{\circ} \mathrm{C}$ for $5 \mathrm{~min}, 35$ cycles of denaturation at $94{ }^{\circ} \mathrm{C}$ for $30 \mathrm{~s}$, annealing at $55.5^{\circ} \mathrm{C}$ for $30 \mathrm{~s}$, and extension at $72{ }^{\circ} \mathrm{C}$ for $30 \mathrm{~s}$, followed by a final extension at $72{ }^{\circ} \mathrm{C}$ for $1 \mathrm{~min}$. S. epidermidis ATCC 35984 and S. epidermidis ATCC 12228 were included as positive and negative control strains, respectively. PCR products were then analyzed by electrophoresis on $1.5 \%$ agarose gel at $100 \mathrm{mV}$ for $45 \mathrm{~min}$; the gel was stained with 
ethidium bromide and observed with UV light. GelPilot 100-bp Plus Ladder (Qiagen) was employed as molecular weight marker.

\section{Results}

\subsection{Phenotypic identification}

Seventy-four CNS isolates were selected among 130 presumptive staphylococcal strains isolated from 120 bulk tank milk samples. They were subjected to phenotypic identification by API Staph system. Table 2 shows source and API 20 Staph profile of each detected isolate. The most frequently observed species were Staphylococcus xylosus with 21/74 isolates $(28.4 \%)$ and Staphylococcus chromogenes with 15/74 isolates (20.3\%). Nine out of 74 isolates (12.2\%) were identified as Staphylococcus sciuri, 7/74 (9.4\%) as Staphylococcus hominis, 5/74 (6.8 \%) as Staphylococcus haemolyticus, 4/74 (5.4\%) as Staphylococcus capitis, 3/74 (4.1\%) as Staphylococcus cohnii ssp. cohnii, 3/74 (4.1\%) as Staphylococcus saprophyticus, and 3/74 (4.1\%) as Staphylococcus simulans. Moreover, 1 out of 74 isolates $(1.3 \%)$ was detected for the species Staphylococcus caprae, S. epidermidis, Staphylococcus lentus, and Staphylococcus warneri.

\subsection{Enterotoxins and TSST-1 gene detection}

Tables 2 and 3 show results obtained for detection of genes encoding enterotoxins and TSST-1 production in the $74 \mathrm{CNS}$ isolates. Thirty-four out of 74 isolates $(45.9 \%)$ were negative for all tested genes, while $40 / 74$ isolates $(54.1 \%)$ presented at least one gene encoding for enterotoxin production. Twenty-five out of 74 isolates $(33.8 \%)$ presented only one gene and 15/74 (20.3\%) two or more genes in association. The sea gene was the most frequently observed. It was detected in 31 out of the 74 isolates (41.9\%). Among these, 17/31 (54.8\%) showed only the sea gene and 10/31 (32.3\%) harbored sea gene in association with sec-1, 2/31 (6.5\%) with see, 1/31 (3.2\%) with tst, and 1/31 (3.2\%) with both sec-1 and tst (Table 3). The sea gene was found in all the CNS species isolates with exception of $S$. epidermidis and $S$. warneri.

The sec-1 gene was detected in 19/74 isolates $(25.7 \%)$; in particular, it was the only detected toxin gene in $7 / 19(36.8 \%)$ isolates, while in $10 / 19(52.6 \%)$ isolates, it was associated with sea, in 1/19 (5.3\%) isolate with tst and in 1/19 $(5.3 \%)$ isolate with both sea and tst. The sec-1 gene was found in S. chromogenes, S. epidermidis, S. hominis, S. saprophyticus, and S. warneri.

The see gene was observed in 3 out of the $74(4.1 \%)$ analyzed isolates. They belonged to the species $S$. haemolyticus, $S$. hominis, and $S$. sciuri. One of these isolates $(33.3 \%)$ presented only the see gene and 2/3 (66.7\%) presented see gene in association with sea. The seb and sed genes were not detected in tested isolates.

The $t s t$ gene was detected in 3/74 (4.1\%) of the tested isolates. They belonged to the species $S$. saprophyticus and $S$. cohnii ssp. cohnii. Among these, 1/3 (33.3\%) showed tst associated with sea, 1/3 (33.3\%) with sec-1, and 1/3 (33.3\%) with both sea and sec-1. 
Table 2 Species, source, phenotypic, and genetic profiles of the 74 studied isolates

\begin{tabular}{|c|c|c|c|c|c|c|c|c|c|}
\hline Species & Source & Api profile & sea & $s e b$ & $\sec -1$ & see & sed & tst & icaA/icaD \\
\hline S. cap 1 & B & 6202111 & + & - & - & - & - & - & + \\
\hline S. cap 2 & $\mathrm{C}$ & 6122012 & - & - & - & - & - & - & - \\
\hline S. cap 3 & $\mathrm{C}$ & 6102010 & - & - & - & - & - & - & - \\
\hline S. cap 4 & $\mathrm{C}$ & 6106000 & - & - & - & - & - & - & - \\
\hline S. caprae 1 & A & 6636101 & + & - & - & - & - & - & - \\
\hline S. chrom 1 & A & 6516013 & + & - & - & - & - & - & - \\
\hline S. chrom 2 & A & 6716053 & + & - & - & - & - & - & - \\
\hline S. chrom 3 & A & 6516013 & + & - & - & - & - & - & - \\
\hline S. chrom 4 & $\mathrm{~A}$ & 6716053 & + & - & + & - & - & - & - \\
\hline S. chrom 5 & $\mathrm{C}$ & 6516013 & + & - & + & - & - & - & - \\
\hline S. chrom 6 & $\mathrm{C}$ & 6516013 & + & - & + & - & - & - & - \\
\hline S. chrom 7 & A & 6716053 & - & - & - & - & - & - & - \\
\hline S. chrom 8 & A & 6716013 & - & - & - & - & - & - & - \\
\hline S. chrom 9 & $\mathrm{~A}$ & 6716051 & - & - & - & - & - & - & - \\
\hline S. chrom 10 & $\mathrm{~A}$ & 6716013 & - & - & - & - & - & - & - \\
\hline S. chrom 11 & A & 6716053 & - & - & - & - & - & - & - \\
\hline S. chrom 12 & A & 6716053 & - & - & - & - & - & - & - \\
\hline S. chrom 13 & A & 6716013 & - & - & - & - & - & - & - \\
\hline S. chrom 14 & A & 6736013 & - & - & - & - & - & - & - \\
\hline S. chrom 15 & $\mathrm{~A}$ & 6516013 & - & - & - & - & - & - & - \\
\hline S. cohn ssp. cohn 1 & $\mathrm{C}$ & 6614100 & + & - & + & - & - & + & - \\
\hline S. cohn ssp. cohn 2 & $\mathrm{C}$ & 6614100 & + & - & - & - & - & - & - \\
\hline S. cohn ssp. cohn 3 & A & 6236101 & - & - & - & - & - & - & - \\
\hline S. epid 1 & $\mathrm{C}$ & 6606113 & - & - & + & - & - & - & - \\
\hline S. haemolyt 1 & $\mathrm{~B}$ & 6612111 & + & - & - & - & - & - & - \\
\hline S. haemolyt 2 & $\mathrm{C}$ & 6730141 & + & - & - & - & - & - & - \\
\hline S. haemolyt 3 & $\mathrm{~B}$ & 6632111 & - & - & - & + & - & - & - \\
\hline S. haemolyt 4 & $\mathrm{C}$ & 6730151 & - & - & - & - & - & - & - \\
\hline S. haemolyt 5 & $\mathrm{~B}$ & 6636111 & - & - & - & - & - & - & - \\
\hline S. homin 1 & $\mathrm{~B}$ & 6636113 & + & - & + & - & - & - & + \\
\hline S. homin 2 & $\mathrm{~B}$ & 6636113 & + & - & + & - & - & & + \\
\hline S. homin 3 & $\mathrm{~B}$ & 6636113 & + & - & + & - & - & - & + \\
\hline S. homin 4 & $\mathrm{~B}$ & 6636113 & + & - & + & - & - & - & + \\
\hline S. homin 5 & $\mathrm{~B}$ & 6636113 & + & - & + & - & - & - & - \\
\hline S. homin 6 & B & 6636113 & + & - & - & + & - & - & + \\
\hline S. homin 7 & $\mathrm{~B}$ & 6636113 & + & - & - & - & - & - & + \\
\hline S. lent 1 & A & 6737750 & + & - & - & - & - & - & - \\
\hline S. saprophyt 1 & $\mathrm{~B}$ & 6736111 & + & - & + & - & - & - & - \\
\hline S. saprophyt 2 & $\mathrm{~B}$ & 6632103 & + & - & - & - & - & + & + \\
\hline
\end{tabular}


Table 2 (continued)

\begin{tabular}{|c|c|c|c|c|c|c|c|c|c|}
\hline Species & Source & Api profile & sea & seb & sec- 1 & see & sed & tst & icaA/icaD \\
\hline S. saprophyt 3 & $\mathrm{C}$ & 6610100 & - & - & + & - & - & + & - \\
\hline S. sciu 1 & $\mathrm{C}$ & 6736050 & + & - & - & + & - & - & - \\
\hline S. sciu 2 & $\mathrm{C}$ & 6736050 & + & - & - & - & - & - & - \\
\hline S. sсiи 3 & A & 6336150 & + & - & - & - & - & - & - \\
\hline S. sciu 4 & $\mathrm{C}$ & 6736050 & + & - & - & - & - & - & - \\
\hline S. sciu 5 & A & 6736050 & - & - & - & - & - & - & - \\
\hline S. sciu 6 & $\mathrm{C}$ & 6736150 & - & - & - & - & - & - & - \\
\hline S. sciu 7 & $\mathrm{C}$ & 6736150 & - & - & - & - & - & - & - \\
\hline S. sciu 8 & A & 6736150 & - & - & - & - & - & - & + \\
\hline S. sciu 9 & A & 6336150 & - & - & - & - & - & - & + \\
\hline S. simul 1 & A & 6536053 & + & - & - & - & - & - & - \\
\hline S. simul 2 & A & 6432053 & - & - & - & - & - & - & - \\
\hline S. simul 3 & $\mathrm{C}$ & 6510451 & - & - & - & - & - & - & - \\
\hline S. $x y l 1$ & A & 6736751 & + & - & + & - & - & - & - \\
\hline S. $x y l 2$ & B & 6776652 & + & - & - & - & - & + & + \\
\hline S. $x y l 3$ & B & 6734452 & + & - & - & - & - & - & + \\
\hline S. $x y l 4$ & $\mathrm{C}$ & 6736571 & + & - & - & - & - & - & + \\
\hline S. xyl 5 & $\mathrm{C}$ & 6736473 & - & - & + & - & - & - & - \\
\hline S. $x y l 6$ & $\mathrm{C}$ & 6736552 & - & - & + & - & - & - & - \\
\hline S. $x y l 7$ & $\mathrm{C}$ & 6737753 & - & - & + & - & - & - & - \\
\hline S. $x y l 8$ & $\mathrm{C}$ & 6736751 & - & - & + & - & - & - & - \\
\hline S. $x y l 9$ & $\mathrm{C}$ & 6730551 & - & - & + & - & - & - & - \\
\hline S. $x y l 10$ & $\mathrm{C}$ & 6736452 & - & - & - & - & - & - & - \\
\hline S. xyl 11 & $\mathrm{C}$ & 6776452 & - & - & - & - & - & - & - \\
\hline S. xyl 12 & $\mathrm{C}$ & 6337652 & - & - & - & - & - & - & - \\
\hline S. xyl 13 & $\mathrm{C}$ & 6736552 & - & - & - & - & - & - & - \\
\hline S. xyl 14 & B & 6736452 & - & - & - & - & - & - & - \\
\hline S. xyl 15 & B & 6736552 & - & - & - & - & - & - & - \\
\hline S. xyl 16 & B & 6777653 & - & - & - & - & - & - & - \\
\hline S. xyl 17 & A & 6736452 & - & - & - & - & - & - & - \\
\hline S. xyl 18 & A & 6777450 & - & - & - & - & - & - & - \\
\hline S. xyl 19 & A & 6736452 & - & - & - & - & - & - & - \\
\hline S. xyl 20 & A & 6336750 & - & - & - & - & - & - & + \\
\hline S. xyl 21 & A & 6732453 & - & - & - & - & - & - & + \\
\hline S. warn 1 & $\mathrm{C}$ & 6230113 & - & - & + & - & - & - & - \\
\hline Total $(n=74)$ & & & 31 & 0 & 19 & 3 & 0 & 3 & 15 \\
\hline
\end{tabular}

+ positive, - negative, A Livorno farm, B Grosseto farm, $C$ Pisa farm, S. capit S. capitis, S. capr S. caprae, S. chrom S. chromogenes, S. cohn S. cohnii ssp. cohnii, S. epid S. epidermidis, S. haemolyt S. haemolyticus, S. homin S. hominis, S. lent S. lentus, S. saprophyt S. saprophyticus, S. sciu S. S. sciuri, S. simul S. simulans, S. xyl S. xylosus, $S$. warn $S$. warneri 


\subsection{Biofilm gene detection}

The icaA and icaD genes were found in 15/74 (20.3\%) isolates, which belonged to the species $S$. capitis, $S$. hominis, $S$. saprophyticus, $S$. sciuri, and $S$. xylosus. The icaA and $i c a D$ genes were always found in association (Table 2). Table 4 shows the results for detection of icaA and icaD genes together with results for enterotoxin gene detection.

Among the $15 \mathrm{icaA}$ - and icaD-positive isolates, 5/15 (33.3\%) were also sea positive and 4/15 (26.7\%) showed sea and sec-1 genes, 1/15 (6.7\%) sea and see genes, and $1 / 15(6.7 \%)$ sea and tst genes. Four out of the $15 \mathrm{ica}$-positive isolates $(26.7 \%)$ had no genes encoding for enterotoxin production.

\section{Discussion}

The risk of CNS food poisoning related to consumption of dairy products is often considered as a minor issue. As a matter of fact, to date, the direct implication of CNS isolated from milk or dairy products in food poisoning has not been reported (Irlinger 2008). On the other hand, CNS are ubiquitous in ruminant environment and could represent a concern, especially for some countries, such as Italy, where raw milk is available for consumers and goat, sheep, and bovine raw milk is used for cheese production. For sure, the prevalence and the role of enterotoxigenic CNS strains in milk and dairy products need to be clarified (Podkowik et al. 2013). Several authors focused on the presence of enterotoxin producers among CNS strains from milk, dairy, and food products, highlighting a general low incidence: back in 1996, VernozyRozand et al. reported that $5 \%$ of CNS strains isolated from goat's milk and cheese were able to produce enterotoxin E. In a study by Zell et al. (2008), 35 strains isolated

Table 3 Enterotoxins and toxic shock syndrome toxin-1 gene association in tested CNS isolates

\begin{tabular}{|c|c|c|c|c|c|}
\hline Species & sea $/$ sec -1 & sea/see & sea/tst & $\sec -1 /$ tst & sea/sec-1/tst \\
\hline S. capitis $(n=4)$ & 0 & 0 & 0 & 0 & 0 \\
\hline S. caprae $(n=1)$ & 0 & 0 & 0 & 0 & 0 \\
\hline S. chromogenes $(n=15)$ & 3 & 0 & 0 & 0 & 0 \\
\hline S. cohnii ssp. cohnii $(n=3)$ & 0 & 0 & 0 & 0 & 1 \\
\hline S. epidermidis $(n=1)$ & 0 & 0 & 0 & 0 & 0 \\
\hline S. haemolyticus $(n=5)$ & 0 & 0 & 0 & 0 & 0 \\
\hline S. hominis $(n=7)$ & 5 & 1 & 0 & 0 & 0 \\
\hline S. lentus $(n=1)$ & 0 & 0 & 0 & 0 & 0 \\
\hline S. saprophyticus $(n=3)$ & 1 & 0 & 1 & 1 & 0 \\
\hline S. sciuri $(n=9)$ & 0 & 1 & 0 & 0 & 0 \\
\hline S. simulans $(n=3)$ & 0 & 0 & 0 & 0 & 0 \\
\hline S. xylosus $(n=21)$ & 1 & 0 & 0 & 0 & 0 \\
\hline S. warneri $(n=1)$ & 0 & 0 & 0 & 0 & 0 \\
\hline Total $(n=74)$ & 10 & 2 & 1 & 1 & 1 \\
\hline
\end{tabular}


Table 4 Enterotoxins and toxic shock syndrome toxin-1 gene profiles of icaA/icaD-positive isolates

\begin{tabular}{|c|c|c|c|c|c|}
\hline & Negative & sea & sea/sec-1 & sea/see & sealtst \\
\hline S. capitis $(n=1)$ & 0 & 1 & 0 & 0 & 0 \\
\hline S. hominis $(n=6)$ & 0 & 1 & 4 & 1 & 0 \\
\hline S. saprophyticus $(n=1)$ & 0 & 0 & 0 & 0 & 1 \\
\hline S. sciuri $(n=2)$ & 2 & 0 & 0 & 0 & 0 \\
\hline S. xylosus $(n=5)$ & 2 & 3 & 0 & 0 & 0 \\
\hline Total $(n=15)$ & 4 & 5 & 4 & 1 & 1 \\
\hline
\end{tabular}

from several foods were investigated for enterotoxin production: 18 strains produced at least one toxin; sed and seh were the most common. More recently, both Aye et al. (2014) and Ruaro et al. (2013) reported a low incidence of potential enterotoxin producer among CNS strains isolated from raw milk, cheese, and foodstuff. Nevertheless, several studies have identified CNS as a potential reservoir of enterotoxin production determinants. Rall et al. (2010) showed that $26.2 \%$ out of 65 CNS strains isolated from Brazilian Minas cheese harbored genes encoding for enterotoxin production. The sea gene was the most frequently found (12 strains), followed by $\sec$ (3 strains) and seb (2 strains), whereas sed was not found. Recently, de Freitas Guimarães et al. (2013) reported that $66 \%$ of strains among 128 CNS isolated from bovine milk harbored enterotoxin gene determinants; the most frequently identified were sea, seb, and sec. Another recent study by Rall et al. (2014) reports 61 strains carrying enterotoxin genes $(47.5 \%)$ among 128 analyzed CNS. However, in the same paper, the low incidence of toxins producers $(1.6 \%)$ is still highlighted.

Our study seems to be in accordance with the recent literature concerning the presence of CNS in milk and dairy products (de Freitas Guimarães et al. 2013; Rall et al. 2010; Zell et al. 2008) and could suggest a potential role of CNS isolated from bovine bulk tank milk in Tuscan (Central Italy) as a source of enterotoxin genes.

The dominant CNS species that we detected from milk samples via API 20 Staph were S. xylosus, S. chromogenes, and S. sciuri; however, some authors argued that API Staph ID, both 20 and 32, could lead to a misidentification of strains at species level (Park et al. 2011a; Sampimon et al. 2009). All staphylococcal species showed at least a strain positive for pathogenic factors (SEs, biofilm, or tsst-1 genes).

The most remarkable percentage of positive isolates $(54.1 \%)$ was related to the presence of genes codifying for enterotoxin production. Moreover, some isolates showed the presence of genes related to biofilm (20.3\%) and TSST-1 (4.1\%) production as well.

The most frequently found gene was sea $(41.9 \%)$, followed by sec-1 $(25.7 \%)$ and see $(4.1 \%)$. These data seems to be in accordance with those reported from Rall et al. (2014). None of the tested CNS harbored seb or sed genes. The $37.5 \%$ of enterotoxin gene-positive isolates showed two or more genes in association, with sea/sec as the most frequent. It is interesting to notice that all isolates belonging to the species S. caprae, S. epidermidis, S. hominis, S. lentus, S. saprophyticus, and S. warneri presented at least one SE gene. 
Genes responsible for biofilm formation, icaA and icaD, were found in $20.3 \%$ of the tested isolates. Only five of the considered species ( $S$. capitis, S. hominis, S. saprophyticus, S. sciuri, and S. xylosus) were involved. Ability to form biofilm is considered to be determinant for the persistence of CNS in dairy production environment (Tremblay et al. 2013).

Eleven of the tested isolates showed the simultaneous presence of SEs and ica genes. All harbored sea gene, alone $(n=5)$ or in association with other SE genes $(n=6)$. Interestingly, all the isolates belonging to S. hominis $(n=7)$ were positive for SE genes, and among these, six also presented icaA/D genes.

The simultaneous presence of genes encoding for biofilm formation in potential toxin producer strains could give them the ability to easily persist in the environment end/or in milking machine, plumbing, and tank, especially after conventional disinfectant treatments. Since an increasing number of publications report enterotoxin genes from CNS as poorly expressed and/or unstable (Aye et al. 2014; Park et al. 2011b; Ruaro et al. 2013), a qualitative and quantitative study on the ability of our isolates to produce enterotoxins and biofilm could be useful to understand the potential role of these bacteria in contamination of milk with SEs. The lack of enterotoxin production ability would explain the reason why, generally, CNS are rarely involved in food poisonings, despite the high incidence of enterotoxin genes detected in their genomes.

However, the remarkable percentage of positivity for SE genes suggests a potential role of CNS in spreading enterotoxigenic determinant among other microorganisms; thus, the concern about the presence of CNS in milk and dairy products still remains. CNS could represent an important reservoir of virulence-associated genes that significantly contribute to the evolution of $S$. aureus enterotoxigenicity (Kassem 2011). Hence, CNS contamination of milk and milk products should be monitored as well as the presence of $S$. aureus. It is important to understand the real role of CNS in food, and based on the presence of enterotoxin genes, CNS should not be ignored in epidemiological investigations of foodborne outbreaks.

Conflict of interest Authors declare that they have no conflict of interest.

Statement of human and animal rights This article does not contain any studies with human or animal subjects performed by any of the authors.

\section{References}

Argudin MÁ, Mendoza MC, Rodicio MR (2010) Food poisoning and Staphylococcus aureus enterotoxins. Toxins 2:1751-1773

Aye R, Gautam A, Reyaz A, Vinson H, Gibbs PS (2014) Evaluation of selected toxigenic genes and antimicrobial agent susceptibility in Staphylococcus spp isolated from foods purchased from North Dakota grocery stores. J Food Nutr Disord 3:3

Bartelt M (2000) Diagnostic bacteriology, a study guide. FA Davis Co, Philadelphia, PA 
Bendahou A, Lebbadi M, Ennanei L, Essadqui FZ, Abid M (2008) Characterization of Staphylococcus species isolated from raw milk and milk products (lben and jben) in North Morocco. J Infect Dev Ctries 2(3):218225

de Freitas Guimarães F, Nóbrega DB, Richini-Pereira VB, Marson PM, de Figueiredo Pantoja JC, Langoni H (2013) Enterotoxin genes in coagulase-negative and coagulase-positive staphylococci isolated from bovine milk. J Dairy Sci 96(5):2866-2872

Dinges MM, Orwin PM, Schlievert PM (2000) Exotoxins of Staphylococcus aureus. Clin Microbiol Rev 13(1):16-34

Gad GFM, El-Feky MA, El-Rehewy MS, Hassan MA, Abolella H, El-Baky RMA (2009) Detection of icaA, icaD genes and biofilm production by Staphylococcus aureus and Staphylococcus epidermidis isolated from urinary tract catheterized patients. J Infect Dev Ctries 3(5):342-351

Irlinger F (2008) Safety assessment of dairy microorganisms: coagulase-negative staphylococci. Int J Food Microbiol 126:302-310

Jablonski LM, Bohach GA (1999) Staphylococcus aureus. In: Doyle MP, Beuchat LR, Montville TJ (eds) Food microbiology: fundamentals and frontiers. ASM Press, Washington DC, pp 353-375

Johnson WM, Tyler SD, Ewan EP, Ashton FE, Pollard DR, Rozee KR (1991) Detection of genes for enterotoxins, exfoliative toxins, and toxic shock syndrome toxin 1 in Staphylococcus aureus by the polymerase chain reaction. J Clin Microbiol 29(3):426-430

Jorgensen HJ, Mork T, Caugant DA, Kearns A, Rørvik LM (2005) Genetic variation among Staphylococcus aureus strains from Norwegian bulk milk. Appl Environ Microbiol 71(12):8352-8361

Kassem II (2011) Chinks in the armor: the role of the nonclinical environment in the transmission of Staphylococcus bacteria. Am J Infect Control 39:539-541

Le Loir Y, Baron F, Guatier M (2003) Staphylococcus aureus and food poisoning. Genet Mol Res 2:63-76

Lina G, Bohach GA, Nair SP, Hiramatsu K, Jouvin-Marche E, Mariuzza R (2004) Standard nomenclature for the superantigens expressed by Staphylococcus. J Infect Dis 189(12):23342336

Lüthje P, Schwarz S (2006) Antimicrobial resistance of coagulase-negative staphylococci from bovine subclinical mastitis with particular reference to macrolide-lincosamide resistance phenotypes and genotypes. J Antimicrob Chemother 57:966-969

Michael O (2004) Virulence factors of the coagulase-negative staphylococci. Front Biosci 9:841863

Oliveira AM, Padovani CR, Miya NT, Sant'Ana AS, Pereira JL (2011) High incidence of enterotoxin D producing Staphylococcus spp. in Brazilian cow's raw milk and its relation with coagulase and thermonuclease enzymes. Foodborne Pathog Dis 8(1):159-163

Omoe K, Hu D, Takahashi-Omoe H, Nakane A, Shinagawa K (2005) Comprehensive analysis of classical and newly described staphylococcal superantigenic toxin genes in Staphylococcus aureus isolates. FEMS Microbiol Lett 246:191-198

Otto M (2013) Staphylococcal infections: mechanisms of biofilm maturation and detachment as critical determinants of pathogenicity. Annu Rev Med 64:175-188

Park JY, Fox LK, Seo KS, McGuire MA, Park YH, Rurangirwa FR, Sischo WM, Bohach GA (2011a) Comparison of phenotypic and genotypic methods for the species identification of coagulase-negative staphylococcal isolates from bovine intramammary infections. Vet Microbiol 147(1):142-148

Park JY, Fox LK, Seo KS, McGuire MA, Park YH, Rurangirwa FR, Sischo WM, Bohach GA (2011b) Detection of classical and newly described staphylococcal superantigen genes in coagulase-negative staphylococci isolated from bovine intramammary infections. Vet Microbiol 147(1-2):149-154

Payne D, Wood JM (1974) The incidence of enterotoxin production in strains of Staphylococcus aureus isolated from food. J Appl Bacteriol 37(3):319-25

Piette A, Verschraegen G (2009) Role of coagulase-negative staphylococci in human disease. Vet Microbiol 134:45-54

Podkowik M, Park JY, Seo KS, Bystroń J, Bania J (2013) Enterotoxigenic potential of coagulase-negative staphylococci. Int J Food Microbiol 163:34 40

Rall VLM, Vieira FP, Rall R, Vieitis RL, Fernandes A Jr, Candeias JMG, Cardoso KFG, Araújo JP Jr (2008) PCR detection of staphylococcal enterotoxin genes in Staphylococcus aureus strains isolated from raw and pasteurized milk. Vet Microbiol 132:408-413

Rall VLM, Sforcin JM, de Deus MFR, de Sousa DC, Camargo CH, Godinho NC, Galindo LA, Soares TCS, Araújo JP (2010) Polymerase chain reaction detection of enterotoxins genes in coagulase-negative staphylococci isolated from Brazilian Minas cheese. Foodborne Pathogens Dis 7:1121-1123 
Rall VLM, Miranda ES, Castilho IG, Camargo CH, Langoni H, Guimarães FF, Araújo Junior JP, Fernandes Júnior A (2014) Diversity of Staphylococcus species and prevalence of enterotoxin genes isolated from milk of healthy cows and cows with subclinical mastitis. J Dairy Sci 97(2):829-837

Resch M, Nagel V, Hertel C (2008) Antibiotic resistance of coagulase-negative staphylococci associated with food and used in starter cultures. Int J Food Microbiol 127:99-104

Ruaro A, Andrighetto C, Torriani S, Lombardi A (2013) Biodiversity and characterization of indigenous coagulase-negative staphylococci isolated from raw milk and cheese of North Italy. Food Microbiol 34(1): 106-11

Sampimon OC, Zadoks RN, De Vliegher S, Supre K, Haesebrouck F, Barkema HW, Sol J, Lam TJ (2009) Performance of API Staph ID 32 and Staph-Zym for identification of coagulase-negative staphylococci isolated from bovine milk samples. Vet Microbiol 136:300-305

Schmid D, Fretz R, Winter P, Mann M, Höger G, Stöger A, Ruppitsch W, Ladstätter J, Mayer N, de Martin A, Allerberger F (2009) Outbreak of staphylococcal food intoxication after consumption of pasteurized milk products, June 2007, Austria. Wien Klin Wochenschr 121:125-131

Seo YS, Lee DY, Rayamahji N, Kang ML, Yoo HS (2008) Biofilm-forming associated genotypic and phenotypic characteristics of Staphylococcus spp. isolated from animals and air. Res Vet Sci 85:433-438

Stewart CM, Cole MB, Schaffner DW (2003) Managing the risk of staphylococcal food poisoning from cream-filled baked goods to meet a food safety objective. J Food Prot 66(7):1310-1325

Tenhagen BA, Köster G, Wallmann J, Heuwieser W (2006) Prevalence of mastitis pathogens and their resistance against antimicrobial agents in dairy cows in Brandenburg, Germany. J Dairy Sci 89(7): 2542-51

Tremblay YD, Lamarche D, Chever P, Haine D, Messier S, Jacques M (2013) Characterization of the ability of coagulase negative staphylococci isolated from the milk of Canadian farms to form biofilms. J Dairy Sci 96:234-246

Vanderhaeghen W, Piepers S, Leroy F, Van Coillie E, Haesebrouck F, De Vliegher S (2014) Invited review: effect, persistence, and virulence of coagulase-negative Staphylococcus species associated with ruminant udder health. J Dairy Sci. doi:10.3168/jds.2013-7775

Zell C, Resch M, Rosenstein R, Albrecht T, Hertel C, Götz F (2008) Characterization of toxin production of coagulase-negative staphylococci isolated from food and starter cultures. Int $\mathrm{J}$ Food Microbiol 127:246-251 